\title{
Electrical design of a 100MW plant in the North of Chile
}

\author{
TIANLE ZHANG, XIANGSAI FENG, XU ZHU \\ Shanghai Solar Energy Research Center, Shanghai 200241, China \\ zhangtianle@solarcell.net.cn, fengxiangsai@solarcell.net.cn \\ zhuxu@solarcell.net.cn
}

Keywords: Electrical Design, Photovoltaic Power Station, Chile.

Abstract. This project considered the preliminary design of a 100MW photovoltaic power station on the Atacama Desert in the North of Chile, which provided flexibility for further project construction.

\section{Introduction}

The economic expansion of Chile has led to a GDP growth of over $170 \%$ in the last 10 years [1], pushing up the demand for electricity, which has been covered by a steady raise of its production, from 42.2 TWh in 2002 to $65.8 \mathrm{TWh}$ in 2012 [2]. Due to its geography, Chile presents five major independent electric transmission systems. The main two, providing $99 \%$ of the country's energy [3], are the SIC (Interconnected Central System) in the centre of the country and the SING (Interconnected System of the Grand North), covering the northern most $800 \mathrm{~km}$ of the territory [4]. In 2013 the SIC generated 47.8 TWh, while the SING generated 15.4 TWh [3]. The electricity supply generated in SING is $99 \%$ fossil fuel dependent [5]. At the country level, hydro energy coversaround one third of the electricity generated [5], while more than $60 \%$ of it is produced from fossil fuels, which are almost entirely imported [6], while around one third is provided by hydro energy [5]. This structure has affected the security of the electricity supply in the past, due to specific climatic events (that altered the hydro-electricity generation) and due to fuel import problems [4] [7]. Over the years, copper mining has been the main consumer of electricity in the country, requiring $32 \%$ of the total [8]. This number reached $83 \%$ in the SING zone in 2013 (12.8TWh from a total of $15.414 \mathrm{TWh}$ ) [9] [3].

To improve the security of electricity supply, the Chilean government has recently adopted policies to support projects that harvest non-conventional renewable energies (NCRE). The target for the electricity produced by NCRE is set at $20 \%$ of the domestic demand by 2025 [10]. As a reference: the share of solar generation by 2013 was $0.02 \%$ in the SING and $0.01 \%$ in the SIC [5].

\section{Solar Plant Construction, Technical}

\section{Selection of panels}

A thin-film photovoltaic cell (TFPV) is a new type solar cell that is made by depositing one or more thin layers, or thin film of photovoltaic material. Cadmium telluride $(\mathrm{CdTe})$ is the predominant thin-film technology often used for outdoor application. Calyxo is a company that works on the development of a highly-innovative technology for the manufacture of thin-film-solar-modules. Calyxo modules produce more energy at temperature above $25^{\circ} \mathrm{C}$ than other solar panels because of a lower temperature coefficient.

From the performance @STC, up to 9\% more energy per year compared with a same power rating PV panel can be produced by Calyxo solar system. At low light and high temperatures, it has high energy/performance ratio(kwh/kWP).

For the solar panel system design in Calama, Calyxo CX-62 63wp can be a suitable choice which is a thin-film PV panel product. The electrical and mechanical characterictics are as follows: 
Table 1: Mechanical data of PV panel Calyxo CX-62 63wp

\begin{tabular}{|l|l|l|l|}
\hline \multicolumn{2}{|l|}{ Electrical data } & $\begin{array}{l}\text { Standard test } \\
\text { conditions }\end{array}$ & $\begin{array}{l}\text { Normal operating } \\
\text { cell temperature }\end{array}$ \\
\hline Nominal power( $\pm 5 \%)$ & PMPP $_{\text {MW }}[$ & 62.5 & 47.5 \\
\hline Current at max.Power & IMPP $[\mathrm{A}]$ & 1.45 & 1.2 \\
\hline Voltage at max. Power & V $_{\text {MPP }}[\mathrm{V}]$ & 42.7 & 40.2 \\
\hline Short Circuit current & ISC [A] & 1.77 & 1.43 \\
\hline Open Circuit Voltage & V VC $[\mathrm{V}]$ & 60.4 & 57.3 \\
\hline
\end{tabular}

Table 2: Electrical data of PV panel Calyxo CX-62 63wp. Source (Calyxo, 2011)

\begin{tabular}{|l|l|}
\hline Mechanical data \\
\hline Cell type & Cadmium telluride $(\mathrm{CdTe})$ \\
\hline Length*width & $1200 \mathrm{~mm} * 600 \mathrm{~mm}$ \\
\hline Weight & $12.0 \mathrm{~kg}$ \\
\hline Connector & Y-Sol4 \\
\hline
\end{tabular}

\section{Determine the total number of panels}

The location of the solar PV system project is assumed in dessert near Calama, where is a depopulated zone and vast territory. In this case, the space between each row and string of PV panel can be ignored when accounting the amount. Also, In Calama, the irradiation in January is up to $260.8 \mathrm{~W} / \mathrm{m}^{2}$ and $170.8 \mathrm{~W} / \mathrm{m}^{2}$ in June, making N-S axis tracking have the advantage to fully use of solar resources.

As discussed above, when determining the number of PV panel, the approximate number can be calculated by the limitation of power.

$$
\mathrm{N}_{p}=\frac{P_{\text {total }}}{P_{\text {panel }}}=\frac{100000000}{63}=1587301
$$

The design of this Calama case choses 1600000 panels.

\section{Selection of inverter}

As a system technology specialist, SMA has been developing and distributing high-quality PV inverters and innovative technology for intelligent energy management for over 30 years. The technology and service solutions for all photovoltaic applications offer users more efficiency and independence in meeting their energy needs. The Sunny Central CP-US series, which is produced by SMA, can be connected to any utility grid or three-phase commercial service, making it suitable for the 100MW large scale Calama case.

Going for a symmetrical system, the 1600000 panels should be divided into 200 groups of 8000 panels, each group connected to one of the phase through a 3-phase inverter.

The rated power of each group is $8000 \times 63 \mathrm{~W}=504000 \mathrm{~W}$. Model Sunny central 500CP-US has a rated power of $500 \mathrm{KW}$ which gives a inverter/array power ratio: $8500 \mathrm{KW} / 504000 \mathrm{~W}=0.992$. This result is inside the 0.8-1.0 range. Because the inverter has inputs between 6 and 9 , choose 8 panels in series and 125 panels in parallel as a whole to connect to an input.

The maximum inverter input voltage is $1000 \mathrm{~V}$. The open circuit voltage of the panels at $57.3 \mathrm{~V}$. Because $\mathrm{V}_{\text {oc }}$ goes up with reducing temperature and increasing irradiance, the worst combined temperature and irradiance condition for Calama is $\mathrm{T}_{\mathrm{a}}=10.9^{\circ} \mathrm{C}$ with irradiation $5.06 \mathrm{KWH} / \mathrm{M}^{2}$. Choose the temperature is $10^{\circ} \mathrm{C}$ as the worst case. Use the equation as follows.

$$
T_{c}=\left(T_{N O C T}-T_{\alpha, N O C T}\right)\left[\frac{G_{t}}{G_{t, N O C T}}\right]\left[1-\frac{\eta_{e}}{(\tau \alpha)}\right]+T_{a}
$$


The cell temperature is $7.71^{\circ} \mathrm{C}$. Then use the $\mathrm{V}_{\mathrm{OC}}$ temperature coefficient from the PV panel data sheet, the voltage increase is $(25-7.71) \times 0.22=3.8 \mathrm{~V}, \mathrm{~V}_{0 \mathrm{C}}$ will therefore be around $68 \mathrm{~V}$. For a string with 8 panels, the total open circuit voltage will be $488.8 \mathrm{~V}$, which is less than the maximum inverter input voltage of $1000 \mathrm{~V}$. Finally the inverter is acceptable.

The MPP voltage for the panels is $65.5 \mathrm{~V}$ at the standard testing conditions (STC) of $\mathrm{G}_{\mathrm{t}}=1 \mathrm{KW} / \mathrm{m}^{2}$ and $\mathrm{T}_{\mathrm{c}}=25^{\circ} \mathrm{C}$. For the extreme low temperature in Calama, the temperature is $10.9^{\circ} \mathrm{C}$. Hence the voltage rise will be $13 \mathrm{~V}$ and the maximum power point voltage $\mathrm{V}_{\mathrm{mpp}}=78.5 \mathrm{~V}$. The maximum power point voltage for the whole 8 panel string will be $628 \mathrm{~V}$.For the extreme high temperature in Calama, the temperature is $18.9^{\circ} \mathrm{C}$ and the irradiation is $318 \mathrm{~W} / \mathrm{m}^{2}$. The voltage rise can be calculated by the same equation as above, which is $14.64^{\circ} \mathrm{C}$. Hence the voltage drop will be $(25-14.64) \times 0.22=2.28 \mathrm{~V}$ and the maximum power point voltage $\mathrm{V}_{\mathrm{mpp}}=476.6$. The MPP voltage range is between 430 and 820 . Thus all the voltage design constants are respected.

The current constraint is also respected as the maximum current of each string will be $1.16 \times 125=145 \mathrm{~A}$, while the inverter limit is $1069 \mathrm{~A}$.

\section{Support electrical infrastructure (according requirements and operation)}

The project design should include the construction of a substation, where the transformer, fault clearance mechanisms, connections and switchboards are placed. Most transmission lines in the area work at $220 \mathrm{kV}$. Hence, a transformer is needed to adjust the voltage from the output of the inverters (at $23 \mathrm{kV}$ ) to the transmission system.

To account for future expansions and to avoid entering high loading regions that increase the losses, the loading of transmission lines and transformer during normal operation at rated power of the PV farm was considered to be $66 \%$ of their rated capacity. Hence, the transformer and the transmission lines to use should be rated for 150 MVA. Regarding the requirement of handling of reactive power (imposed by the SING regulations), this is supported by the chosen inverter. As in any project of this magnitude, spares should be considered to cover elements damaged during construction and operation. Here, $1 \%$ of spare parts was considered regarding panels and inverters.

\section{To summarize:}

I The array consists of $1600000 \times 63 \mathrm{~W}$ thin film panels.

I Use $200 \times$ Sunny Central 500CP-US inverters.

I 8 panels in series and 125 panels in parallel are connected together to fed into the input of each inverter, and each inverter uses 8 inputs.

I $\mathrm{P}_{\text {array }}=1600000 \times 63=100.8 \mathrm{MW}$ and $\mathrm{P}_{\text {inverter }}=200 \times 500 \mathrm{KW}$

All design constraints have been respected

\section{Conclusion}

Despite the vast potential the Atacama Desert in Chile offers to solar PV developments, investors have to keep in mind factors of potential customers, the possibility of regulatory changes, and technical risks. These factors may limit financial profitability in the future. However, nowadays Chile appears to be the most attractive market for utility scale projects. The current energy needs of an expanding mining industry and, in the near future, the announced connection of the SING and the SIC (central grid, feeding the vast majority of the population and industry), makes the Atacama desert a promising ground for future investment in solar energy projects. If there is a real explosion of projects in the future, a risks to be assessed would be, on the economic perspective, the saturation of the electrical market, which may lead to a drop in the electricity price, forecasted until now at 80 US\$/MWh for the SING. A not minor risk, which unfortunately cannot be forecasted, is the seismic nature of the country. Hence, the entire infrastructure needs to be built according to seismic standards. 


\section{Reference}

[1] The World Bank, "Data - GDP,” 2015. [Online]. Available: http://data.worldbank.org/indicator/NY.GDP.MKTP.CD. [Accessed 21 Mar 2015]. [2] OECD, "Electricity Generation," 2015. [Online]. Available: http://data.oecd.org/energy/electricity-generation.htm\#indicator-chart. [Accessed 21 Mar 2015]. [3] Comision Nacional de Energia, Chile, "Producción real por sistema," $2013 a$. [4] IEA, "Oil and Gas Security - Chile," 2012. [Online]. Available: http://www.iea.org/publications/freepublications/publication/chile_2012.pdf. [Accessed 5 Dec2014]. [5] Ministerio de Energia, "Agenda de Energia," Ministerio de Energia, Chile, 2014.

[6] IEA, "IEA Statistics," 2014d. [Online]. Available: http://www.iea.org/statistics/statisticssearch/report/? year=2012\&country $=$ CHILE\&product=Balances. [Accessed 5 Dec 2014]. [7] IEA, “CHILE ENERGY POLICY REVIEW 2009,” OECD/IEA, 2009.

[8] Consejo Minero, "Energia y cambio climatico," 2014. [Online]. Available: http://www.consejominero.cl/ambitos-estrategicos/energia-y-cambio-climatico/. [Accessed $21 \mathrm{Mar}$ 2015].

[9] Comision Chilena del Cobre, "Proyeccion del consumo de energia electrica de la mineria delcobre en Chile al 2025," 2013.

[10]Ministerio de Energia, "Gobierno promulga Ley 20/25 y anuncia entrada en vigencia de Ley deConcesiones," 14 Oct 2013a. [Online]. Available:

http://www.minenergia.cl/ministerio/noticias/generales/gobierno-promulga-ley-20-25-yanuncia. html. [Accessed 5 Dec 2014]. 